\title{
Balancing Economic Development and Environmental Conservation for a New Governance of Alpine Areas
}

\author{
Maria Giulia Cantiani ${ }^{1}$, Clemens Geitner ${ }^{2}$, Christine Haida ${ }^{3}$, Federica Maino ${ }^{4}$, Clara Tattoni ${ }^{1}$, \\ Daniele Vettorato ${ }^{4,5}$ and Marco Ciolli ${ }^{1, *}$ \\ 1 Department of Civil Environmental and Mechanical Engineering, University of Trento, Via Mesiano 77, \\ Trento 38123, Italy; maria.cantiani@unitn.it (M.G.C.); clara.tattoni@gmail.com (C.T.) \\ 2 Institute of Geography, University of Innsbruck, Innsbruck A-6020, Austria; Clemens.Geitner@uibk.ac.at \\ 3 AlpS GmbH, Innsbruck A-6020, Austria; haida@alps-gmbh.com \\ 4 Institute for Regional Development and Location Management-European Academy of \\ Bolzano/Bozen (EURAC), Viale Druso, 1, Bolzano/Bozen 39100, Italy; \\ federica.maino@eurac.edu (F.M.); daniele.vettorato@eurac.edu (D.V.) \\ 5 Institute for Renewable Energy-European Academy of Bolzano/Bozen (EURAC), \\ Viale Druso, 1, Bolzano/Bozen 39100, Italy \\ * Correspondence: marco.ciolli@unitn.it; Tel.: +39-0461-882625; Fax: +39-0461-882672
}

Academic Editors: Nabin K. Malakar, Rajan Ghimire, Jhalendra Rijal and Pradeep Wagle Received: 23 June 2016; Accepted: 9 August 2016; Published: 15 August 2016

\begin{abstract}
In the Alpine environment, Man has always been directly dependent on mountain ecosystems. Social mechanisms have created specific models of governance, capable of assuring the persistence of ecosystems and their capacity to provide essential goods and services. In recent decades, however, dramatic changes have occurred, such as climate change and changes in land use. The complexity common to all linked human-natural environment systems is extremely marked in the Alpine areas and this makes it difficult to understand how resilient these systems may be. Many research questions arise, in particular as to the comprehension and quantification of the impact of changes on the capacity of ecosystems to produce goods and services in a sustainable way, and the possibility of local mechanisms of governance to adapt to both current and future changes. Reasons and effects of change are analysed from the perspective of the specific issues of governance. The importance of the Ecosystems Services (ESs) concept is acknowledged and the necessity for a dynamic assessment of ESs, taking into account people's values and expectations, is particularly stressed. Through a careful analysis of selected papers and case studies, the main gaps in current knowledge are identified and directions for further research are provided.
\end{abstract}

Keywords: governance; sustainable development; landscape scale; ecosystem services; decisions support systems; public participation; Alps

\section{Introduction}

One of the main problems experienced in natural resources management and planning is that frequently the decision makers have no clear perception of the bonds that unite the population to its home-place, nor do they wholly recognise the ample and complex bundle of values and meanings that individuals and communities attribute to ecosystems [1-4]. This actually often goes far beyond the concerns of managers and planners. In the same way, what is also generally disregarded is the role played by sentiment and emotions in affecting people's care for their territory and the scale of values implicit in their attitudes and behaviour [5,6]. Emotions are often criticised for being irrational [4-6] and considered irrelevant in practical terms. Rather than being underestimated, emotions should 
be understood as a key to interpreting whatever values may link policy makers, managers and population. In fact emotions are often a signal that powerful underlying values are at stake [6]. This kind of detachment of the politicians and the public agencies from the people may be particularly problematic when dealing with mountain ecosystems, especially in a period of rapid change such as the one that the European mountains, in particular the Alps, are experiencing currently [1]. These territories, actually, are currently confronted both by general environmental problems such as global warming and to local socio-economic transformations. However, maintaining vital communities in the mountains (a problem common to the entire Alpine Region) is today an essential condition for the conservation of the landscape in all its diversity, for the physical protection of the territory and for the safeguarding of all those values associated with the local culture and traditions [7]. Moreover, it is an important requirement for the well-being of many urban populations living in towns and cities of the plains $[1,8]$.

According to Schmithüsen and Wild-Eck [9], technicians base their decisions on their own personal knowledge and professional experience. If it is necessary, they try to compensate for the fact that they lack direct knowledge of public opinion. They do this either by interpreting their personal opinion as matching that of the general public, or by adopting as "public opinion" that which comes out from the mass media and political debate [1]. Both of these efforts at compensation produce a misleading and unrealistic image of reality. In fact, nowadays a strong need is felt for new tools capable of assuring a better understanding of people's values, needs and expectations on the part of technicians and policy makers, and a flowing, effective communication in both senses $[10,11]$. New tools, at the same time, are needed in order to ease technical and political choices when planning at the landscape level and looking at sustainable development of mountainous regions. Quite often, in this case, nature conservation issues and economic growth expectations happen to be pitted one against the other, when they would be better balanced in order to shape a sustainable development of the territory [11]. With this aim, an essential prerequisite is that local communities be actively involved in the management of their own territory.

Starting from these considerations, in the present paper we analyse reasons and effects of change in the Alpine Region. Our viewpoint is that of the specific issues of governance that occur in these mountainous territories where, traditionally, natural and semi-natural ecosystems have long formed the basis for local community life, providing it with a wide range of benefits.

The modern concept of Ecosystem Services (ESs) perfectly features conditions and processes through which ecosystems sustain human life and meet the people's needs, both material and non-material [12]. Our paper acknowledges the importance of a dynamic assessment of ESs and stresses the necessity for a valuation which also takes into account people's values and expectations. Through a careful analysis of selected papers and case studies (the latter carried out in Alpine areas), we try to identify the main gaps in current knowledge and provide directions for further research.

\section{The Alpine Region: A Rapidly Changing Environment}

"Throughout human evolution, human societies have developed in close interaction with the natural environment, which has shaped their cultural identity, value systems, and language" [12] (p. 195).

After World War Two, dramatic socio-economic changes, already begun in industrialized countries, accelerated greatly. Urbanisation, technological evolution, the development of transport networks, and more recently, globalisation have brought about profound change in lifestyles. In this context there was an inevitable weakening of those close, direct relations that for centuries bound human communities to natural resources, assuring Humankind's survival. Although the phenomenon did not manifest itself everywhere simultaneously, it was, nevertheless, widespread and extremely rapid [13-15]. This phenomenon often caught those responsible for natural resources policy and management totally unprepared. The results of such change are clearly observable in the transformation of the landscape that characterises our times [15-19]. 
The changing relationship between Man and Nature is reflected in a different order of values expressed by the population with regard to natural ecosystems: their appraisal in fact changes when they no longer guarantee the daily income [20].

In mountainous regions, and particularly in the Alps, the problem is deeply felt nowadays and merits special consideration. Whilst indeed forming part of the European panorama, the Alpine range has its own peculiarity: straddling countries with different histories, cultures and traditions, the Alpine regions nevertheless show many characteristics in common, a feature of their own existence as a mountainous region (Figure 1). The Alps are a mountain system situated between the Mediterranean area and continental Europe. They have always been densely populated and have also hosted many linguistic minorities, being an important gateway for people in both directions, North and South of the continent $[7,8]$. The Alpine area did not remain exempt from the dramatic socio-economic transformation which affected Europe, but specific effects and implications arose as a consequence of its being a mountainous territory [1].

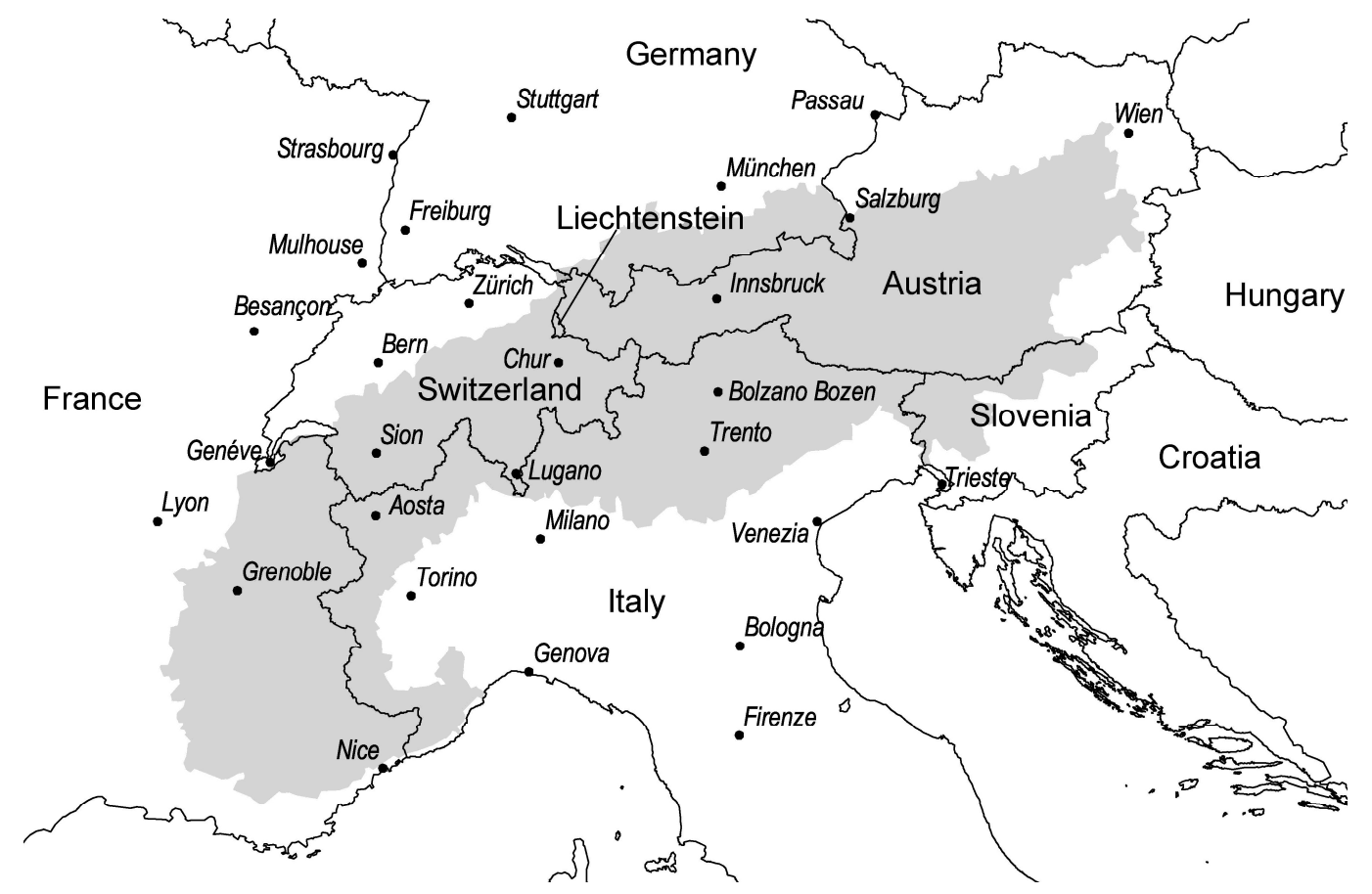

Figure 1. The Alpine Region (adapted from Cantiani et al. [1]).

In the Alpine environment, characterised by a great geomorphological and climatic diversity, local communities have always been directly and very heavily dependent on mountain ecosystems. Despite being an environment in itself inhospitable and physically fragile, it has made it possible for Man to survive, thanks to his ability to adapt and to take advantage of the benefits offered by different mountain ecosystems [21].

Since remote times, human activities have, on the one hand, aimed at the production of food and raw materials necessary to satisfy the needs of the local community; on the other hand, humans have also tried to construct settlements suitable for habitation, particularly in relation to the need to guard the population from natural disasters [21,22]. The peculiarities of mountain habitats imposed diversified production strategies and appropriate forms of ownership and management; territories situated at high altitude, where grazing and gathering activities prevailed, were generally commonly owned and collectively managed, while the meadows and fields situated at lower altitude, mostly private property, were individually managed [23]. It is indisputable that in some historical periods in certain Alpine areas the local equilibrium has been disrupted by human activities, such as mining or the over-exploitation of pasture lands and forests, leading to a breakdown in the ecosystem and the 
extinction of some species. Nevertheless, the Alpine environment as a whole has allowed for a recovery of healthy environmental conditions in a relatively short period [1,21,23-25]. The aforementioned activities, in fact, led to the creation in the mountain ecosystems (forests, meadows and pastures, fields) of an equilibrium which, whilst in many ways far removed from what would naturally occur, was nevertheless able to guarantee the conservation and functioning of those ecosystems [1]. The traditional Alpine landscape is actually the result of a multiplicity of management methods of varying intensities, tailored to local circumstances, which gave rise to a self-sufficient system of supply and demand. This was matched by the way of life, characterised by its rhythms, knowledge, customs and values [24-26]. The isolation of the valleys, in fact, enhanced utmost diversification both from the social and cultural point of view. In guaranteeing the continuity of constant production, traditional activities carried out in the mountains, even though within certain limits, secured the physical protection of the territory, assured the maintenance of an elevated biodiversity and collaterally-probably inadvertently-assured the preservation of the landscape in all its diversity [21]. This "cultural" landscape, where it still exists, perfectly reflects the relationship that links local communities to their ecosystems.

In the Alps, until fairly recently, the importance of the mountain ecosystems in ensuring the wellbeing of local communities was abundantly clear to all; the role of the public agencies in charge of conservation, planning and management of the mountain ecosystems has also been widely acknowledged so far. Today, however, a new order of priorities of values often appears, leading to a gap between the population on the one hand and technicians and policy makers on the other [27].

\section{A Problem of Governance}

Social mechanisms, which have evolved over time, have created specific models of governance in the Alpine areas [1]. For a long time these models have assured the persistence of mountain ecosystems and their capacity to provide essential goods and services.

The dramatic changes of recent decades, however, have altered the general framework and threaten the traditional balance: climate change on the one hand and changes in land-use on the other, with the addition of the financial and economic crisis of recent years [7].

The complexity common to all linked human-natural environment systems is particularly marked in the Alpine areas [21-26] and this makes it even more difficult to understand what consequences may follow [1]. Will the mechanisms of governance be able to adapt to the current and future changes? Will people with particular responsibility in governance-among these policy makers and technicians-understand the reasons underlying the changes and their effects and will they be ready to cope with them?

Among the many different problems affecting the Alpine regions, some seem especially serious and are posing important challenges in relation to a sustainable development of the areas involved, but not only these areas. In fact, they may also have serious negative repercussions on urban populations living far away.

- The geographical position of the Alpine Range makes it vulnerable to the impacts of climate change, as is already well-known, and there is great uncertainty as to alpine ecosystems' capacity for resilience. A thorough knowledge of the ecological processes activated by climate change is not yet available, but much research on this topic is currently being carried out. Suggestions have been made that the effects of climate change on the provision of goods and services may be multi-faceted [17,28,29], with their impacts depending on location and services [30-33]. It is also thought that demand for certain services might increase [34], causing discrepancies between supply and demand. As far as governance mechanisms are concerned, the coordination of policies-climate, water management, agriculture and forestry, energy, housing, tourism and transport-is generally still lacking and there is a great need for research in order to investigate the new opportunities of development that might be created by climate change, such as those within the ambit of agriculture and forestry, green economy and renewable energy production [35]. 
- The effects of land-use changes are now even more impressive than those connected to climate change, due to the fact that they stimulate quite rapid responses in ecological processes. Two contrasting trends are manifest when dealing with land-use changes: intensification in some areas and abandonment in others [36]. Both may have grave consequences on landscape and biodiversity, in terms of alteration of traditional assets and fragmentation or loss of natural habitats and ecological corridors. However, nowadays, the Alpine environment is affected in particular by the phenomenon of abandonment of traditional activities over large areas, often accompanied by severe depopulation. The ensuing transformation of the landscape, tied up in particular to the rapid and often irreversible loss of open spaces, is already showing negative effects for the conservation of biodiversity [37-42]. In fact cultural landscapes in the Alps have long provided diversified habitats for numerous species, some of which are now endangered. In recent years, the biodiversity emergency has become one of the priorities on the European Union's agenda $[43,44]$. In many valleys, moreover, the rapid advance of forest is leading to an extensive homogenization of landscape and a loss of scenic view. This has a negative impact on summer tourism [37-42]. Other possible negative implications of abandonment are those connected to the protective functions of the forests: forests that over the centuries have been altered by Man, nowadays need forms of management tailor-made to guarantee their stability, functionality, and a capacity for natural regeneration. Regarding intensification, on the other hand, sensitive issues are, among others, those connected to the intensive utilization of meadows [45] or the use of wood biomass for energy supplies [46-48]. These days, in fact, there is increasing interest in the use of wood as a source of energy in order to reach the European objective regarding renewable energy sources [49,50].

- The recent economic-financial crisis is raising serious doubts regarding the model of development, mostly based on mass tourism, which has characterised many valleys of the Alps in the last few decades. The related activities have indeed upset not only the balance in the ecosystems, but also that of human communities, disrupting the traditional modalities of interaction peculiar to a mountain society and causing the collapse of that principle of solidarity which once bound the members of Alpine communities together [1,51]. At the same time, the traditional activities of the primary sector (forestry, agriculture and animal husbandry), which in the past had played a very important role in the lives of local communities, have been gradually abandoned, because they have been confronted with different kinds of problems. Among these, there is an increase in the cost of labour, but without a corresponding increase in the price of the product $[7,42]$. There is also an intrinsic weakness in the sector due to inadequate and ineffective organisation of what the sector has to offer and a lack of marketing strategies to promote the Alpine region's finest local products. Quite often this has also meant a loss of competence and professionalism throughout the entire chain of production. Specific handicaps that the alpine regions share with the other mountainous areas of Europe are a very fragmented ownership structure and practical difficulties in realizing infrastructures, in particular transport networks, and also in guaranteeing services [37]. This really does make these areas less favoured [52]. The current crisis, however, could offer new opportunities for the primary sector, and more generally for a transition towards more sustainable and resource-efficient economic structures, provided that appropriate actions are taken and synergies are sought (such as the sustainable use of wood biomass for energy supply or the provision of high quality dairy products, within initiatives connected to ecotourism) [1].

When dealing with the quite new concept of governance, much debate has been devoted in the last two decades to problems of definition and framework development. The complexity of such a concept is hard to capture in a single definition. Actually many and sometimes contrasting definitions have been suggested. Most of them, however, are based on three aspects: authority, decision-making and accountability [53-56]. In our specific case, governance may be intended as a complex system of relations and decision-making processes, including actors generally not considered in the public arena, which leads to a new model of caring for and managing the public interest at a regional or local level. 
With the adoption in 2001 of the White Paper on Governance on the part of the European Commission [57], governance is acknowledged as a strategic objective of the European Union and the need to open the processes to citizens' involvement is strongly stressed.

A more recent document of the European Union, the Territorial Agenda 2020 [35], makes explicit reference to the specific problems of rural areas, territories often rich in natural and cultural values, but particularly vulnerable. They need, therefore, special attention in order to identify appropriate long-term solutions capable of assuring a vital local economy, by enhancing the creation of environmentally-friendly jobs, attractive living conditions and suitable public services for citizens and enterprises. To this purpose, the importance of a "place-based" approach is stressed to make the most of territorial potential, develop strategies that can address local conditions and foster a harmonious, balanced, sustainable development. A place-based approach makes it possible to deal with the complex problems connected to a sustainable development of a certain area and to meet the particular conditions in a place, engaging local actors from a diverse range of sectors in order to activate collaborative processes of problem solving and decision making. Another very important issue, dealt with in the same document, concerns the growing interdependence of regions, which calls for "continued networking, cooperation and integration between various regions" [35] (p. 4), in order to realize a territorial integration also in cross-border and transnational functional regions.

Such a document definitively focuses attention on the need for a "place-based" and territorially-sound approach to research into issues of governance in the Alpine areas.

\section{The Concept of Ecosystem Services}

The ecosystem services concept is extremely useful when dealing with governance issues and when it is necessary to clarify the relationship that links natural systems and human societies [58]. It refers, in fact, to the benefits (goods and services) that human populations obtain, directly or indirectly, from ecosystems functions, and shows how heavily human well-being depends on healthy ecosystems [12].

Even if the implications revolving around this concept have been known for a long time, the idea of "services" first appears at the end of the 1970s in Westman's assertion [59] that the comprehensive value of benefits provided by ecosystems, called Nature's services, might be taken into consideration in order to better address policy and management decisions. During the 1980s this concept evolved, but it is in the 1990s that it was finally established in the scientific debate, due to several authors who applied this concept through different perspectives of analysis. A great impulse for research in this field was supplied, in particular by the fundamental and much quoted work by Costanza and colleagues [60], which drew policymakers' attention to the notion of valuing ecosystem services and stressed the importance of such valuation. Since then a heated debate has been going on within the international scientific community. The concept has been widely studied, discussed and criticised. Finally, under the impulse of the Millennium Ecosystem Assessment [12] and the follow-up initiative the Economics of Ecosystems and Biodiversity Project [44], the ecosystem services have been integrated into the European political agenda (in environmental, agricultural and biodiversity policies).

The Millennium Ecosystem Assessment's conceptualisation of ESs has provided a solid framework both for researchers' and also practitioners' and policymakers' activities. In this framework, the ESs are classified on the basis of their functions in four categories: (1) provisioning services, referring to the products humans acquire from ecosystems such as food, timber, fibre and water; (2) regulating services, considering the role of ecosystems in the regulation of ecological processes (i.e., water and climate regulation); (3) cultural services, involving the non-material benefits provided by ecosystems (i.e., recreational opportunities, cultural and spiritual values); and (4) supporting services such as soil formation, photosynthesis and nutrient cycling. More recently, ESs have been reclassified into three categories (provisioning, regulating and maintaining, cultural), following the Common International Classification of Ecosystem Services [61]. 
The concept has been then integrated into the landscape scale [62-65] and has proved useful when decisional processes are concerned with environmental matters at regional level. However, great effort in research in this ambit is still required and many research questions arise.

- A comprehensive vision of the different ESs is still lacking. Until now, research has often addressed only a single service or a specific group (i.e., provisioning), and the estimation of its value was mostly carried out from only one perspective (i.e., in monetary terms). For example, after a review of ESs valuation studies conducted in the Alps, Grêt-Regamey and colleagues [63] show that, with few rare exceptions, only one service is taken into consideration. This is often true also in more recent research. In most cases it has to do with biodiversity, scenic beauty, tourism and recreation [66,67], direct protection against natural hazards or hydrogeological regulation [68-70]. Considering the increasing importance attributed nowadays to the multi-functional use of natural and semi-natural ecosystems, research should carefully consider the entire range of ESs and the relative importance of each of them in a specific territory.

- Generally, in the past, the studies focussed on a static situation, whereas today the need for a dynamic approach is acknowledged, in order to highlight the consequences of changes. This is particularly necessary when the concurrent demand for environmental conservation and economic development of a territory have to be conciliated, from the perspective of sustainability. With regard to the above, empirical information is needed as to the quantity, quality and value of the whole of ESs under alternative management regimes, both at local and regional level [62].

- A spatially explicit approach in ESs assessment and valuation is a must when dealing with management and planning at the landscape level, in order to provide credible information for the decision makers and to make communication with the general public easier. Notwithstanding the interest that this topic has recently aroused among scholars $[63,64,71,72]$, increased research effort is needed, in particular when issues of scales are involved, either in space or time [62,73].

- Quite often the results of research are not easily converted into concrete site-specific actions (or rather, in mechanisms of governance), nor are they transferable and applicable to similar situations. What frequently happens is that the institutional context and the governance structures and practices that exist in the investigated area are not taken into due consideration. This causes a discrepancy between theoretical analysis on the one side and practical governance on the other and makes it difficult to "operationalize" ESs for governance [74]. Moreover, in our present time of cost-cutting, decisions concerning forms of management to be supported by public financing (national or European subsidies) are of crucial importance [62]. With this in mind, a greater effort is needed in order to integrate the ESs valuation into the design of models of governance. In this regard, the possible applications of Decision Support Systems (DSS) could be improved in order to ameliorate the structuring of complex environmental problems and supply data for decisions [36,75]. In fact, a DSS, a computer-based information system, may greatly help people to deal with unstructured or semi-structured decision problems and may prove particularly useful in rapidly changing situations.

- The role of some specific ESs should be better analysed and clarified. We do not want, in this paper, to go into the recent discussion about the need for a new ES classification, which excludes supporting services in order to prevent double counting [61,76]. Rather, we intend to focus attention on some particular services especially significant in the Alpine environment. This is the case in tourism. In recent decades the importance of tourism has greatly increased in terms of employment rate and income. It has become the primary source of economic development, even more so in some Alpine valleys, at times triggering off several environmental problems, especially in the case of winter tourism or urbanisation at high altitudes. The Millennium Assessment [12] classifies recreational benefits within cultural services. Actually, most of the activities linked to tourism and the ensuing spin-off, in terms of their effects, are not far from those connected to the production of provisioning services and involve the economic more than the cultural aspect. 
For this reason, when dealing with recreational benefits, a distinction should be made between residents' recreation and tourism from outside.

\section{Lessons Already Learnt and Yet to Be Learnt}

As highlighted above, a sustainable development of mountain territory requires that economic and ecological issues are carefully considered and balanced. To this aim, the consideration of ESs is a tool that has great potential, provided that it is applied to the appropriate scale of analysis. The regional watershed scale makes it possible to address landscape management and planning issues with a concrete and realistic approach $[10,77]$. It allows, at the same time, to generalize and apply the outcomes to similar contexts. At this level, local people and institutions may show a strong proactive approach to the management of natural resources. In this context, management is strictly linked to governance mechanisms, being the focus of political and economic activity. Research on this scale needs to be carried out through case studies, the ideal situation being that of considering not only one single case but, possibly, a few study areas located in different regions sharing, however, certain features.

In the following paragraphs, some methodological considerations are put forward on the basis of previous experiences of the authors in the Alpine environment, carried out by means of case studies $[1,41,50,78-83]$. Among these, in particular, there is the research conducted within the EU Alpine Space Project Recharge.Green [11,84-86].

The design of new models of governance requires a careful assessment and valuation of ESs, based on a thorough knowledge of the existing governance settings and may profitably take advantage of an expressly developed DSS.

\subsection{Ecosystem Services Assessment and Valuation}

In recent years, much effort has been made to systematically categorise ESs $[12,61,87]$. The number of existing classification schemes highlights the difficulties in clearly defining and delineating particular ESs. At the same time, much work has been done on valuing and mapping ESs [61,64,88-90]. Goulder and Kennedy [91] and de Groot and colleagues [62] distinguish between an economic (anthropocentric) and a non-economic (biocentric) approach. A great deal of research has been done for economic valuation, with interesting results for the Alpine Region, too [85,92-95]. The attempt to monetise ESs (Figure 2) is based on the assumption that this is the best way to communicate with the decision makers and ease political choices [96]. That notwithstanding, this approach is not always feasible or convenient. This is the case, for example, when a preliminary assessment of ESs is needed to get a comprehensive idea of values and interests at stake in a certain area, to structure ESs regarding priorities, needs and impacts and to evaluate the importance of specific ESs in the considered area $[97,98]$. 


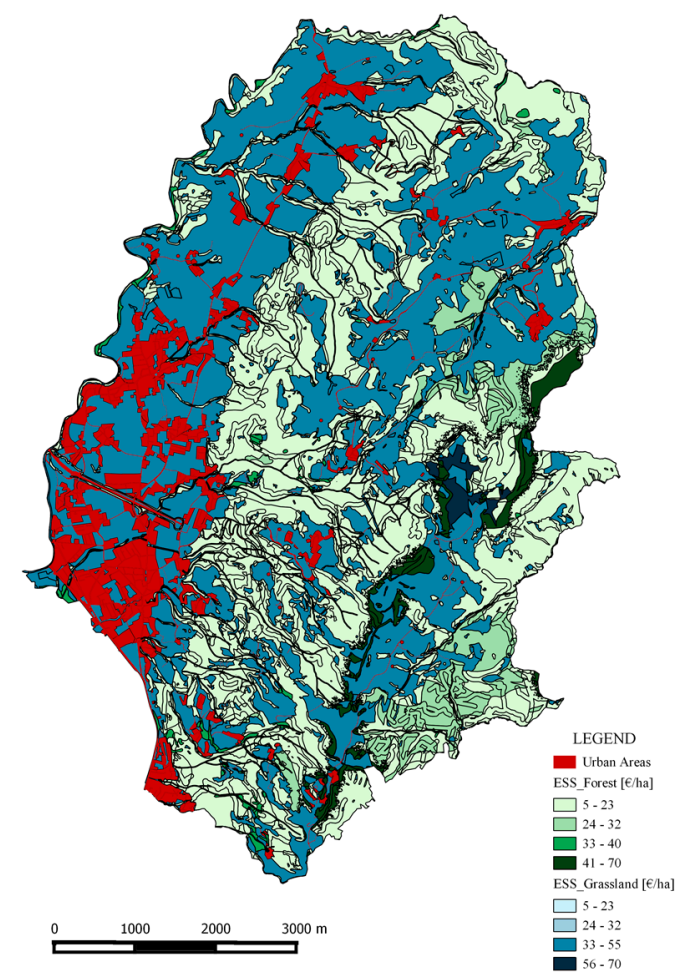

Figure 2. An example of Spatial location of cultural services benefits in Euro/ha (from Paletto et al. [85] modified). The study area represented in the map is the Leiblachtal region in Austria. The study was carried out in the frame of Recharge.Green project.

Among the drawbacks imputed to economic valuation of ESs, we can find limitations due to the fact that it neglects social issues such as fairness and equity in the use of resources; elements of subjectiveness implicit in the choice of the method of valuation; special difficulties when trying to estimate in monetary terms regulating and maintaining services $[93,99,100]$. Monetary valuation is definitely not applicable when dealing with non-instrumental subjective values (such as spiritual values, identity, cultural heritage) or non-substitutable natural objects with inherent value [101].

One common biocentric approach for valuing and mapping ESs is to use proxies such as land cover data [102] and to link these to other spatial explicit landscape characteristics, to name just a few, elevation, slope [72,103] and cultural heritage sites [73]. Easy to use matrices have been developed $[65,103]$ to evaluate the availability of ESs. Nevertheless, these approaches must be adapted to Alpine landscapes. The Millennium Assessment [12] acknowledges major gaps in information concerning non-marketed services, which are often underestimated. Cultural services, in particular, are difficult to evaluate, also because they are heavily site-specific. Indeed, regarding these intangible services, there are still great challenges in order to define appropriate indicators and to obtain values for them. For this reason, participatory valuation methodologies have been developed which often use well-established techniques such as questionnaires [79,82,104,105], focus groups [106], workshops [107] or systematic reviews [108]. From the results of many studies, though not always carried out in the Alpine regions, it appears clear how important it is that people are involved in the assessment and valuation of ESs.

Moving on from these considerations, we maintain that a non-economic approach may be effective, at least in the early stage of planning when the basic lines of development of a certain area must be established. To assess the services in a comprehensive way, different means may be profitably combined: (a) deriving ESs from the analysis of landscape structures and processes; (b) seeking the advice of experts; (c) involving stakeholders and the public at large (Figure 3). 


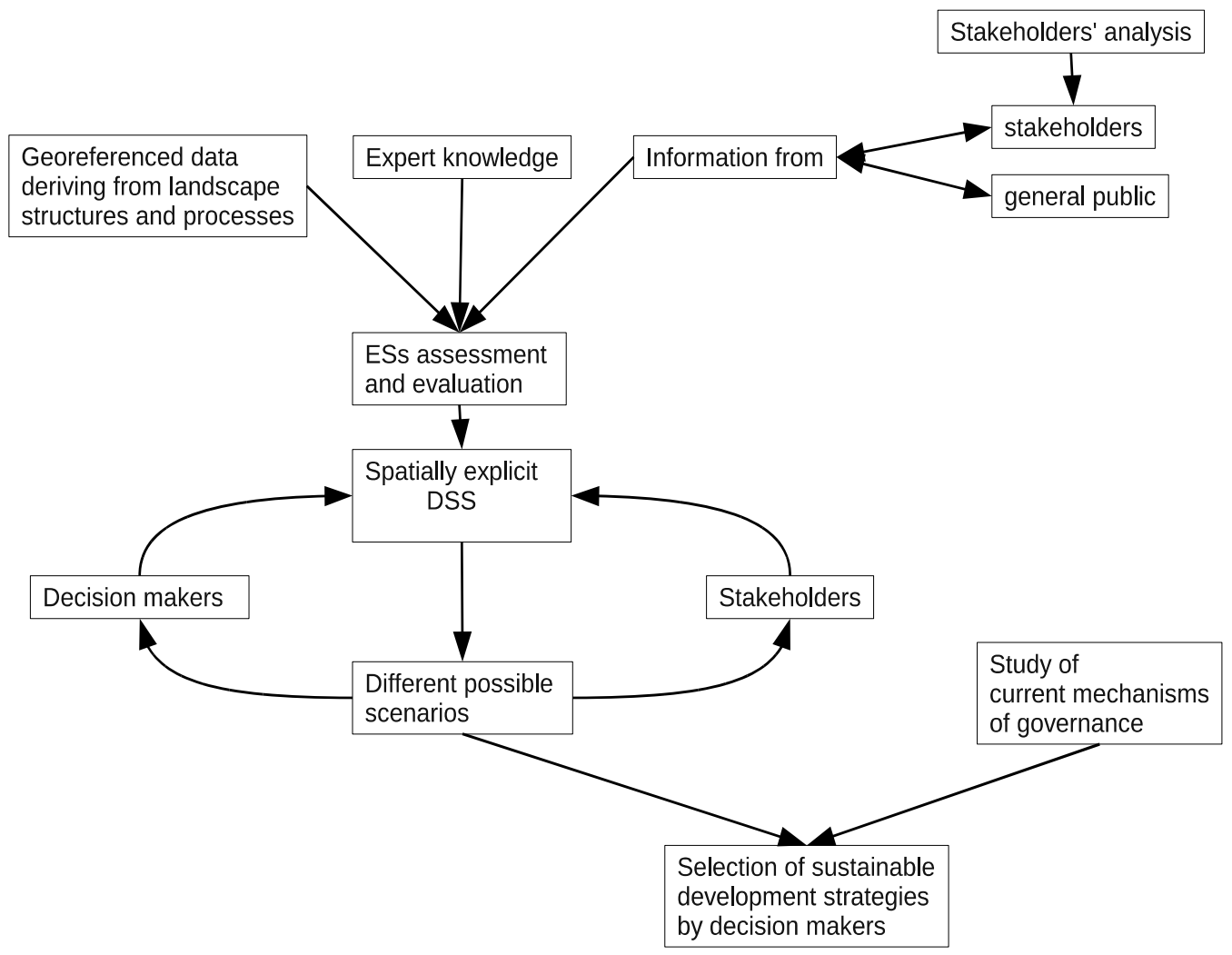

Figure 3. Outline of suggested methodological approach.

(a) All available data must be analysed which relate to land cover, vegetation types, biodiversity, topography, geology and soils, in order to find out the entire range of ESs and the best indicator setting. There are sectors of the Alpine range where it is possible to take advantage of the data sets widely covering the areas of interest and of documents which are often present in great numbers in some Alpine valleys, such as forest- or pasture-management plans, management plans of protected areas and specific scientific studies. If needed, also remote sensing information could be used to obtain certain data, such as those regarding forest stands or morphodynamics. Of course, particular attention is necessary in order to merge and harmonize data derived from different sources.

(b) In addition to the analysis of existing information, expert knowledge may be usefully integrated, in order to bridge possible information gaps. Experts may be involved by means of in-depth interviews or focus groups. They should also be called on to give their advice concerning the impact of changes on the provisioning capacity of the ecosystems. Thanks to such interventions, it should be easier to highlight the main ESs (key ESs) and carry out the selection of the most suitable qualitative and quantitative indicators of the provision capacity of the ecosystems.

(c) Both stakeholders and the general public should be involved in order to assess the key ESs, in a bottom-up approach, and to elicit people's priorities in these services, focusing also on possible future effects of land-use change on ESs. From this point of view, the stakeholders may be considered as "knowledge-holders", too. When examining the non-economic techniques available for the assessment of ESs, we can distinguish between consultative methods (such as questionnaires, in-depth interviews) and deliberative and participatory approaches (i.e., focus groups, Delphi surveys) [62]. Both approaches are effective, in relation to the specific context, and in both cases the stakeholders' analysis is an important prerequisite. It can be profitably carried out by means of the referral sampling method $[109,110]$, which proved to be effective in rural areas [111]. A special team (whose role and composition are highlighted in Section 5.3) could 
be in charge of this task. The stakeholders' involvement can be carried out either by means of in-depth interviews or with workshops, after assessing the specific situation. The involvement of the general public should be conducted with participatory techniques, trying to enable as much interaction as possible among participants. Particular attention should be paid to the participation of young people and the elderly, in order to share knowledge and compare different current interests and demands and also to elicit their ideas on possible related future trends.

Data resulting from participation processes within the local communities must be entered in a Geographic Information System (GIS), in order to obtain georeferenced maps, which can be compared with those derived from the analysis of landscape structures and processes and from expert knowledge. In order to integrate ESs into policy and decision-making, in fact, it is necessary to rely on spatially explicit information.

\subsection{Realisation and Implementation of a Decision Support System}

Decision Support Systems (DSSs) have been used for a long time both in modelling specific scientific topics to speculate on their evolution and in management practice to help decision makers [112-115]. GIS-based DSSs include spatial and geographical dimensions, which allow the addition of a great amount of information and the representation of any phenomenon in a more complete and understandable way [116]. The topics treated in GIS DSSs nowadays involve a wide range of different aspects of environmental concerns, such as biological conservation, forest timber or bioenergy-biomass production, the impact of tourism and landscape planning [48,117-119]. However, many of these models or prototypes represent in detail very specific themes and they often lack a broader vision of the problems that include a multifunctional approach [75], or they are designed to give general information on a macro scale (sovra-national, national or macro-regional level) and such systems are not easily usable to help local decision makers [116,119]. Even if the application of spatially explicit DSSs is regarded as extremely useful, their improvement is greatly needed [120]. We stress the importance of developing a model that can effectively integrate all available data regarding ESs, either technical or deriving from the participatory process, with a holistic approach. The system should take into account the whole data from ESs evaluation and transform it into spatial explicit information. This could be used to produce different scenarios and to create credible alternatives that can be presented to the stakeholders and decision makers in an iterative process. Actually, the effectiveness of scenario development is today widely acknowledged especially when dealing with the complexity and uncertainty created by the current socio-economic and ecological changes [40,121-123]. Another common problem that can be found in the available models of GIS DSSs is that they are often developed in specific software, generally proprietary software, but the complete procedures that make the model work are not available or they are only partially available [75]. This fact makes it very difficult for anyone but the original authors to reproduce the research described in many scientific papers, thus limiting the opportunity to share and improve the GIS DSS models [116], as well as testing them in other contexts. In our opinion, software implementation of GIS DSSs should be carried out using mainly Open Source software [124]. In this way, after being developed for specific study cases, the software could be freely available to be tested in any other context and improved by any subject, public or private, willing to give his contribution, respecting the Open Source licences and giving proper credit to the original authors $[125,126]$. Since the final target of this DSS should be represented by people who are not software experts, during software development particular attention should be given to develop user-friendly graphic interface. GIS data collection and validation is an important task to be achieved. Data regarding forest types, biomass volume, soil and ecological features, as well as all other information functional to modelling development, must be collected for each study area and harmonized. The spatialisation process of the variables can be carried out both by testing new methodologies and using existing literature in this field $[67,69,75]$. The social and economic issues should also be integrated into the model, following different steps which can only be defined in detail once a clear picture of all the data is available. The quality and nature of the data, of 
course, affect the possibility of treating them in a spatial way, so this aspect requires special attention. The system definitely needs a tuning phase that can benefit from the involvement of a selected group of stakeholders (Figure 4) [127].

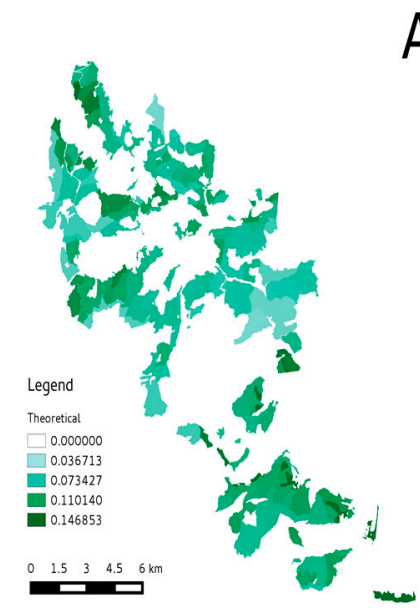

A

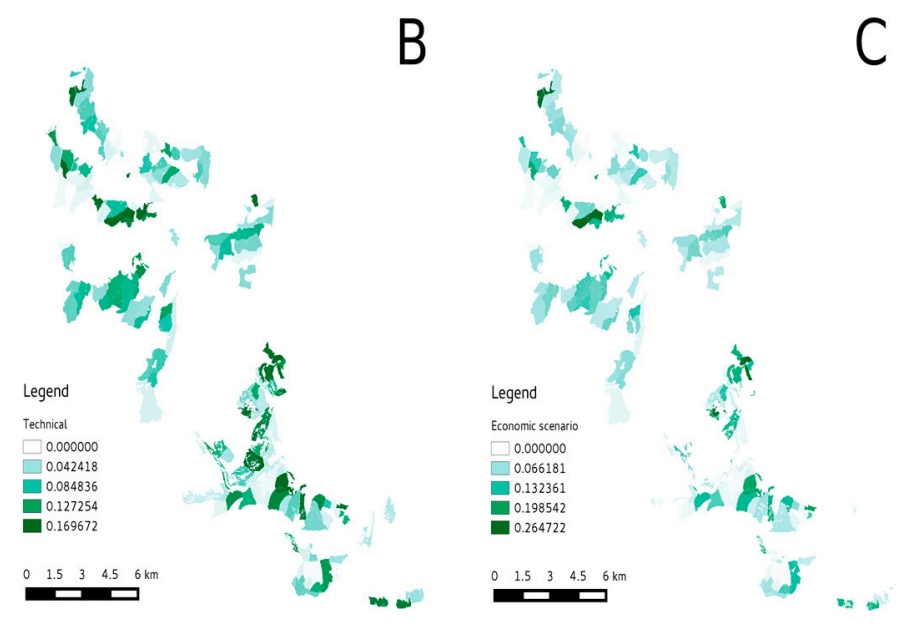

Figure 4. An example of Spatial location of forest biomass for bioenergy in MWh/y for an area in Veneto, Italian Alps (from Ciolli et al. [127] modified). The series of maps is the result of an iterative process between researchers and stakeholders that starting from a theoretical potential (A) introduced technical limits; (B) and identified a plausible scenario; (C) The study was carried out in the frame of Recharge.Green project.

\subsection{Design of a Model of Governance}

Designing new models of governance for Alpine areas is a very challenging topic nowadays. Indeed, the possibility of survival of vital communities in mountainous regions relies on forms of development that know how to combine economic growth and environmental conservation.

Processes aiming at strengthening and reorienting local governance must be based, first of all, on a careful study of the current mechanisms of governance of a certain area and on a thorough knowledge of the actors concerned (Figure 3). For this purpose, a specific "accompanying group" could be created [10]. Such a group should include, in addition to researchers and technicians, one or two local people who act as a point of reference, people who know local mechanisms of governance and the actors involved, and enjoy the trust of the community. This group has proved to be very useful in enabling the comprehension of social and economic assets and on-going dynamics, and to assess the role and responsibility of local stakeholders and decision makers, their power and capacity for interaction and networking [10,128]. The accompanying group can also be entrusted with the task of finding suitable methods to structure local actors' participation, in order to promote well informed, shared decisions.

Thanks to the information provided by the DSS, decision makers may be helped to select sustainable and economically feasible strategies for development. In particular, the scenarios provided by the DSS, may be very useful in weighing up the possible consequences of different choices, showing strong points and drawbacks of each alternative. Mapping and visualisation can also be used as an important tool in enhancing communication with the general public.

A proactive approach should be fostered in order to activate local processes of governance within each area, stimulating creativity and the capacity for finding innovative solutions. In the case of study areas belonging to contiguous geographical regions, there should also be encouragement of networking, integration and cooperation between the different areas. 


\section{Conclusions}

Alpine landscapes provide numerous goods and services useful for both people living there and in surrounding lowlands. However, the supply of these benefits is threatened, mainly because of a high level of habitat loss and fragmentation. One reason for this problem is the lack of acknowledgement of ESs and in particular the lack of comprehension of how change in land use may affect ESs provision and value $[129,130]$. This might be caused by omitting the integration of ESs values into decision making at the scale of regional planning $[11,75]$. To promote a broader view of this human-environment system, it is important to evaluate the current status of mountain ESs and to assess potential changes in their provision and demand in order to give them weight in decision making. Many authors have stressed the importance of such a task, yet without undervaluing the related difficulties and challenges [29,62,131,132].

With the present paper we hope we have contributed to outlining a methodological framework for the assessment of ESs, identification of priorities and evaluation in a spatially explicit form. In this regard, the consideration of the entire range of ESs is essential to address planning at the landscape level. In a post-industrial society, in fact, non-marketed services may be just as, or even more important than the marketed ones. Because of this, the efficacy of participatory techniques for the elicitation of ESs' values should be carefully considered.

Research carried out by means of regional case studies, which takes into proper consideration the existing governance context, shows many interesting and stimulating aspects. It is expected to have not only a local, but also a more widespread relevance in the Alpine area. The results, in fact, could easily be generalised and profitably applied to similar contexts, where new models of development are sought, as an alternative to those based on the consumption of land and its resources.

Acknowledgments: The study was carried out within the following projects: Recharge.Green project "Balancing Alpine Energy and Nature" (http:/ / www.recharge-green.eu), which is part of the Alpine Space Programme, and is co-financed by the European Regional Development Fund; the Recharge.Green project is focused on the analysis of how to reconcile biodiversity conservation of ecosystems and renewable energy production; RISELVITALIA, Ri.Selv.Italia (Common research Program about Sylvicuture in ITALY), Subproject 4.2, National Project funded by the Italian Ministry of agricultural food and forestry policies (MiPAAF); BIOMASFOR project co-funded by the CARITRO Foundation through grant No. 101. We are very grateful to the anonymous referees for their helpful comments and suggestions that helped improving our paper.

Author Contributions: Maria Giulia Cantiani, an expert on governance issues and public participation, designed the study, wrote and conceived the main structure of the paper. Marco Ciolli and Clara Tattoni developed the topic relating to Decision Support Systems and Geographic Information Systems, wrote this part selecting the corresponding case studies and references and enriched in general the text and the references of the paper. Clemens Geitner and Christin Haida contributed to the discussion on the ecosystem services with useful suggestions. Federica Maino and Daniele Vettorato helped to improve the parts dealing with public participation and bioenergy issues with helpful comments. All the authors revised the paper and contributed to the final version.

Conflicts of Interest: The authors declare no conflict of interest.

\section{References}

1. Cantiani, M.G.; de Meo, I.; Paletto, A. What do human values and emotions suggest about forest planning? An international review focusing on the Alpine Region. Int. Rev. Soc. Sci. Humanit. 2013, 1, 228-243.

2. Cheng, A.S.; Kruger, L.E.; Daniels, S.E. "Place" as an Integrating Concept in Natural Resource Politics: Propositions for a Social Science Research Agenda. Soc. Nat. Resour. 2003, 16, 87-104. [CrossRef]

3. Davenport, M.; Anderson, D. Getting from sense of place to place based management: An interpretive investigation of place, meanings and perceptions of landscape change. Soc. Nat. Resour. 2005, 18, 625-641. [CrossRef]

4. O'Brien, E.A. Publics and woodlands in England: Well-being, local identity, social learning, conflicts and management. Forestry 2005, 78, 321-336. [CrossRef]

5. O'Brien, E.A. Human values and their importance to the development of forestry policy in Britain: A literature review. Forestry 2003, 76, 3-17. [CrossRef] 
6. Vining, J.; Tyler, E. Values, emotions and desired outcomes reflected in public responses to forest management plans. Res. Hum. Ecol. 1999, 6, 21-34.

7. Ianni, E.; Geneletti, D.; Ciolli, M. Revitalizing Traditional Ecological Knowledge: A Study in an Alpine Rural Community. Environ. Manag. 2015, 56, 144-156. [CrossRef] [PubMed]

8. Bettelini, D.; Cantiani, M.G.; Mariotta, S. Experiences in participatory planning of designated areas: The Bavona Valley in Switzerland. Forestry 2000, 73, 187-198. [CrossRef]

9. Schmithüsen, F.; Wild-Eck, S. Uses and perceptions of forests by people living in urban areas-Findings from selected empirical studies. Forstwiss. Cent. 2000, 119, 395-408. [CrossRef]

10. Cantiani, M.G. Forest planning and public participation: A possible methodological approach. iForest 2012, 5, 72-82. [CrossRef]

11. Svadlenak-Gomez, K.; Badura, M.; Kraxner, F.; Fuss, S.; Vettorato, D.; Walzer, C. Valuing Alpine ecosystems: The Recharge.Green project will help decision-makers to reconcile renewable energy production and biodiversity conservation in the Alps. Eco. Mont. J. Prot. Mt. Areas Res. 2013, 5, 59-62. [CrossRef]

12. Millenium Ecosystem Assessment. Ecosystems and Human Well-Being: Current States and Trends; Island Press: Washington, DC, USA, 2005.

13. Farcy, C.; Devillez, F. New orientations of forest management planning from an historical perspective of the relations between man and nature. For. Policy Econ. 2005, 7, 85-95. [CrossRef]

14. Owen, R.J.; Duinker, P.N.; Beckley, T.M. Capturing Old-Growth Values for Use in Forest Decision-Making. Environ. Manag. 2009, 43, 237-248. [CrossRef] [PubMed]

15. Rotherham, I.D. The implications of perceptions and cultural knowledge loss for the management of cultural landscapes: A UK case-study. For. Ecol. Manag. 2007, 249, 100-115. [CrossRef]

16. Agnoletti, M. The Conservation of Cultural Landscapes; CAB International Publishing: Wallingford, UK, 2006.

17. Bender, O.; Borsdorf, A.; Fischer, A.; Stötter, H. Mountains under Climate and Global Change Conditions. Research Results in the Alps. In Climate Change-Geophysical Foundations and Ecological Effects; Blanco, J.A., Kheradmand, H., Eds.; InTech: Rijeka, Croatia, 2011; pp. 403-422.

18. Lewis, J.L. Perceptions of landscape change in a rural British Columbia community. Landsc. Urban Plan. 2008, 85, 49-59. [CrossRef]

19. Sitzia, T.; Semenzato, P.; Trentanovi, G. Natural reforestation in changing spatial patterns of rural mountain and hill landscapes: A global overview. For. Ecol. Manag. 2010, 259, 1354-1362. [CrossRef]

20. Lindhagen, A.; Hörnsten, L. Forest recreation in 1977 and 1997 in Sweden: Changes in public preferences and behaviour. Forestry 2000, 73, 143-151. [CrossRef]

21. Messerli, P. Mensch und Natur im Alpinen Lebensraum. Risiken, Chancen, Perspektiven; Verlag Paul Haupt: Bern, Switzerland, 1989. (In German)

22. Netting, R. Balancing on an Alp: Ecological Change and Continuity in a Swiss Mountain; Cambridge University Press: Cambridge, UK, 1981.

23. Viazzo, P.P. Upland Communities: Environment, Population and Social Structure in the Alps since the Sixteenth Century; Cambridge University Press: Cambridge, UK, 1989.

24. Cole, J.W.; Wolf, E.R. The Hidden Frontier: Ecology and Ethnicity in an Alpine Valley; Academic Press: New York, NY, USA, 1974.

25. Sibilla, P. Approdi e Percorsi-Saggi di Antropologia Alpina; Leo Olschki Editore: Firenze, Italy, 2012.

26. Wolf, E.R. Cultural Dissonances in the Italian Alps. Comp. Stud. Soc. Hist. 1962, 5, 1-14. [CrossRef]

27. Cantiani, M.G.; Bettelini, D.; Mariotta, S. Participatory Forest Planning: A chance of communication between forest service and local community. In Proceedings of the International Conference "Forestry Meets the Public", Rüttihubelbad, Switzerland, 8-11 October 2001; FAO/ECE/ILO: Bern, Switzerland, 2002; pp. 249-263.

28. Howe, C.; Suich, H.; van Gardingen, P.; Rahman, A.; Mace, G.M. Elucidating the pathways between climate change, ecosystem services and poverty alleviation. Curr. Opin. Environ. Sustain. 2013, 5, 102-107. [CrossRef]

29. Massarutto, A. Water in climate change: A Background Report of CIPRA; Compact No 03/2011; CIPRA International: Schaan, Liechtenstein, 2011.

30. Elkin, C.; Gutiérrez, A.G.; Leuzinger, S.; Manusch, C.; Temperli, C.; Rasche, L.; Bugmann, H. A $2{ }^{\circ} \mathrm{C}$ warmer world is not safe for ecosystem services in the European Alps. Glob. Chang. Biol. 2013, 19, 1827-1840. [CrossRef] [PubMed] 
31. Lorencova, E.; Frelichova, J.; Nelson, E.; Vackar, D. Past and future impacts of land use and climate change on agricultural ecosystem services in the Czech Republic. Land Use Policy 2013, 33, 183-194. [CrossRef]

32. Munang, R.; Thiaw, I.; Alverson, K.; Liu, J.; Han, Z. The role of ecosystem services in climate change adaptation and disaster risk reduction. Curr. Opin. Environ. Sustain. 2013, 5, 47-52. [CrossRef]

33. Vihervaara, P.; D'Amato, D.; Forsius, M.; Angelstam, P.; Baessler, C.; Balvanera, P.; Boldgiv, B.; Bourgeron, P.; Dick, J.; Kanka, R.; et al. Using long-term ecosystem service and biodiversity data to study the impacts and adaptation options in response to climate change: Insights from the global ILTER sites network. Curr. Opin. Environ. Sustain. 2013, 5, 53-66. [CrossRef]

34. Courbaud, B.; Kunstler, G.; Morin, X.; Cordonnier, T. What is the future of the ecosystem services of the Alpine forest against a backdrop of climate change? Rev. Geogr. Alp. 2010, 98, 412-425. [CrossRef]

35. Agenda, T. Territorial Agenda of the European Union 2020: Towards an Inclusive, Smart and Sustainable Europe of Diverse Regions. In Agreed at the Informal Ministerial Meeting of Ministers Responsible for Spatial Planning and Territorial Development, Gödöllő, Hungary, 19 May 2011; Available online: http: //www.eu2011.hu/files/bveu/documents/TA2020.pdf (accessed on 10 June 2016).

36. Fontana, V.; Radtke, A.; Bossi Fedrigotti, V.; Tappeiner, U.; Tasser, E.; Zerbe, S.; Buchholz, T. Comparing land-use alternatives: Using the ecosystem services concept to define a multi-criteria decision analysis. Ecol. Econ. 2013, 93, 128-136. [CrossRef]

37. Mac Donald, D.; Crabtree, J.R.; Wiesinger, G.; Dax, T.; Stamou, N.; Fleury, P.; Gutierrez Lazpita, J.; Gibon, A. Agricultural abandonment in mountain areas of Europe: Environmental consequences and policy response. J. Environ. Manag. 2000, 59, 47-69. [CrossRef]

38. Orlandi, S.; Probo, M.; Sitzia, T.; Trentanovi, G.; Garbarino, M.; Lombardi, G.; Lonati, M. Environmental and land use determinants of grassland patch diversity in the western and eastern Alps under agro-pastoral abandonment. Biodivers. Conserv. 2016, 25, 275-293. [CrossRef]

39. Sitzia, T.; Trentanovi, G. Maggengo meadow patches enclosed by forests in the Italian Alps: Evidence of landscape legacy on plant diversity. Biodivers. Conserv. 2011, 20, 945-961. [CrossRef]

40. Soliva, R. Agricultural Decline, Landscape Change, and Outmigration: Debating the Sustainability of Three Scenarios for a Swiss Mountain Region. Mt. Res. Dev. 2007, 27, 124-129. [CrossRef]

41. Steinmetz, A.K.; Haida, C.; Geitner, C. Trade-offs of ecosystem services provided by mountain hay meadows under land use change scenarios. In Proceedings of the 5th Symposium for Research in Protected Areas, Mittersill, Austria, 10-12 June 2013.

42. Tattoni, C.; Ciolli, M.; Ferretti, F.; Cantiani, M.G. Monitoring spatial and temporal pattern of Paneveggio forest (Northern Italy) from 1859 to 2006. iForest 2010, 3, 72-80. [CrossRef]

43. EC-DGE. Biodiversity Protection-Beyond 2010. Priorities and Options for Future EU Policy. Available online: http:/ /ec.europe.eu/environment/nature/biodiversity/conference/index_en.htm (accessed on 10 June 2016).

44. TEEB. The Economics of Ecosystems and Biodiversity of National and International Policy Makers-Summary: Responding to the Value of Nature. Available online: http://ec.europa.eu/ environment/nature/biodiversity/economics/index_en.htm (accessed on 10 June 2016).

45. Graf, R.; Müller, M.; Korner, P.; Jenny, M.; Jenni, L. 20\% loss of unimproved farmland in 22 years in the Engadin, Swiss Alps. Agr. Ecosyst. Environ. 2014, 185, 48-58. [CrossRef]

46. Kraxner, F.; Nordström., E.M.; Havlík, P.; Gusti, M.; Mosnier, A.; Frank, S.; Valin, H.; Fritz, S.; Fuss, S.; Kindermann, G.; et al. Global bioenergy scenarios-Future forest development, land-use implications, and trade-offs. Biomass Bioenerg. 2013, 57, 86-96. [CrossRef]

47. Sacchelli, S.; De Meo, I.; Paletto, A. Bioenergy production and forest multifunctionality: A trade-off analysis using multiscale GIS model in a case study in Italy. Appl. Energy 2013, 104, 10-20. [CrossRef]

48. Sacchelli, S.; Bernetti, I.; De Meo, I.; Fiori, L.; Paletto, A.; Zambelli, P.; Ciolli, M. Matching socio-economic and environmental efficiency of wood-residues energy chain: A partial equilibrium model for a case study in Alpine area. J. Clean. Prod. 2014, 66, 431-442. [CrossRef]

49. Fritsche, U.R.; Iriarte, L.; de Jong, J.; Agostini, A.; Scarlat, N. Extending the EU Renewable Energy Directive sustainability criteria to solid bioenergy from forests. Nat. Resour. Forum 2014, 38, 129-140. [CrossRef]

50. Hastik, R.; Basso, S.; Geitner, C.; Haida, C.; Poljanec, A.; Portaccio, A.; Vrščaj, B.; Walzer, C. Renewable energies and ecosystem service impacts. Renew. Sustain. Energy Rev. 2015, 48, 608-623. [CrossRef] 
51. Finger-Stich, A. Les populations alpines et leurs forêts communales. Schweiz. Z. Forstwes. 2006, 157, $453-463$. [CrossRef]

52. Bachmann, P.; Bettelini, D.; Cantiani, M.G. Développements récents de la planification forestière en Italie du Nord et en Suisse. Rev. For. Fr. 1999, 51, 259-274. [CrossRef]

53. Amin, A.; Thrift, N.J. Globalisation, Institutions and Regional Development in Europe; Oxford University Press: Oxford, UK, 1994.

54. Bevir, M. Governance: A Very Short Introduction; Oxford University Press: Oxford, UK, 2013.

55. Commission on Global Governance. Our Global Neighborhood: The Report of The Commission on Global Governance; Oxford University Press: Oxford, UK, 1995.

56. Ruhanen, L.; Scott, N.; Ritchie, B.; Tkaczynski, A. Governance: A review and synthesis of the literature. Tour. Rev. 2010, 65, 4-16.

57. European Commission. European Governance-A White Paper. Available online: http://europa.eu/rapid/ press-release_DOC-01--10_en.htm (accessed on 10 June 2016).

58. Sarkki, S.; Ficko, A.; Grunewald, K.; Nijnik, M. Benefits from and threats to European treeline ecosystem services: An exploratory study of stakeholders and governance. Reg. Environ. Chang. 2015. [CrossRef]

59. Westman, W.E. How much are Nature's services worth? Science 1977, 197, 960-963. [CrossRef] [PubMed]

60. Costanza, R.; d'Arge, R.; De Groot, R.; Farberk, S.; Grasso, M.; Hannon, M.; Limburg, K.; Naem, K.; O'Neil, R.V.; Paruelo, J.; et al. The value of the world's ecosystem services and natural capital. Nature 1997, 387, 253-260. [CrossRef]

61. Haines-Young, R.; Potschin, M. Cices V4.3-Report Prepared Following Consultation on Cices Version 4, August-December 2012, EEA Framework Contract No EEA/IEA/09/003. Available online: http:/ / unstats. un.org/unsd/envaccounting/seearev/GCComments/CICES_Report.pdf (accessed on 10 June 2016).

62. De Groot, R.; Alkemade, R.; Braat, L.; Hein, L.; Willemen, L. Challenges in integrating the concept of ecosystem services and values in landscape planning, management and decision making. Ecol. Complex. 2010, 7, 260-272. [CrossRef]

63. Grêt-Regamey, A.; Walz, A.; Bebi, P. Valuing Ecosystem Services for Sustainable Landscape Planning in Alpine regions. Mt. Res. Dev. 2008, 28, 156-165. [CrossRef]

64. Hermann, A.; Schleifer, S.; Wrbka, T. The Concept of Ecosystem Services regarding Landscape Research: A review. Living Rev. Landsc. Res. 2011, 5, 1-26. [CrossRef]

65. Hermann, A.; Kuttner, M.; Hainz-Renetzeder, C.; Konkoly-Gyuró, É.; Tirászi, Á.; Brandenburg, C.; Allex, B.; Ziener, K.; Wrbka, T. Assessment framework for landscape services in European cultural landscapes: An Austrian Hungarian case study. Ecol. Indic. 2013, 37, 229-240. [CrossRef]

66. Gios, G.; Goio, I.; Notaro, S.; Raffaelli, R. The value of natural resources for tourism: A case study of the Italian Alps. Int. J. Tour. Res. 2006, 8, 77-85. [CrossRef]

67. Grilli, G.; Paletto, A.; De Meo, I. Economic Valuation of Forest Recreation in an Alpine Valley. Balt. For. 2014, 20, 167-175.

68. Dorren, L.K.A.; Berger, F.; Imeson, A.C.; Maier, B.; Rey, F. Integrity, stability and management of protection forests in the European Alps. For. Ecol. Manag. 2004, 195, 165-176. [CrossRef]

69. Notaro, S.; Paletto, A. The economic valuation of natural hazards in mountain forests: An approach based on the replacement cost method. J. For. Econ. 2012, 18, 318-328. [CrossRef]

70. Olschewski, R.; Bebi, P.; Teich, M.; Wissen Hayek, U.; Grêt-Regamey, A. Avalanche protection by forests-A choise experiment in the Swiss Alps. For. Policy Econ. 2012, 15, 108-113. [CrossRef]

71. Maes, J.; Egoh, B.; Willemen, L.; Liquete, C.; Vihervaara, P.; Schägner, J.; Grizzetti, B.; Drakou, E.G.; La Notte, A.; Zulian, G.; et al. Mapping ecosystem services for policy support and decision making in the European Union. Ecosyst. Serv. 2012, 1, 31-39. [CrossRef]

72. Schirpke, U.; Tasser, E.; Tappeiner, U. Predicting scenic beauty of mountain regions. Landsc. Urban Plan. 2013, 111, 1-12. [CrossRef]

73. Willemen, L.; Veldkamp, A.; Verburg, P.; Hein, L.; Leemans, R. A multi-scale modelling approach for analysing landscape service dynamics. J. Environ. Manag. 2012, 100, 86-95. [CrossRef] [PubMed]

74. Primmer, E.; Furman, E. Operationalising ecosystem service approaches for governance: Do measuring, mapping and valuing integrate sector-specific knowledge systems? Ecosyst. Serv. 2012, 1, 85-92. [CrossRef]

75. Sacchelli, S.; Zambelli, P.; Zatelli, P.; Ciolli, M. Biomasfor: An open source holistic model for the assessment of sustainable forest bioenergy. iForest 2013, 6, 285-293. [CrossRef] 
76. Boyd, J.; Banzhaf, S. What are ecosystem services? The need for standardized environmental accounting units. Ecol. Econ. 2007, 63, 616-626. [CrossRef]

77. Ferretti, F.; Di Bari, C.; De Meo, I.; Bianchi, M. ProgettoBosco, a data-driven decision support system for forest planning. Math. Comput. For. Nat. Resour. Sci. 2011, 3, 27-35.

78. De Meo, I.; Cantiani, M.G.; Paletto, A. Landscape Changes and Shareholders' Preferences in the Baselga di Pinè Commons (Italy). In Proceedings of the International Conference on Common Goods from a Landscape Perspective, Florence, Italy, 16-17 January 2014; University of Florence: Florence, Italy, 2014; pp. 171-175.

79. De Meo, I.; Paletto, A.; Cantiani, M.G. The attractiveness of forests: Preferences and perceptions in a mountain community in Italy. Ann. For. Res. 2015. [CrossRef]

80. Geitner, C.; Haida, C.; Lang, P. Aspekte bodenbezogener ecosystem services in den Alpen und ihrer monetären Bewertung. In Jahresbericht der Innsbrucker Geographische Gesellschaft 2008-2010; Universität Innsbruck: Innsbruck, Austria, 2011; pp. 157-173. (In German)

81. Haida, C.; Ruedisser, J.; Tappeiner, U. Ecosystem services in mountain regions: Experts' perception and research intensity. Reg. Environ. Chang. 2015. [CrossRef]

82. Paletto, A.; De Meo, I.; Maino, F.; Cantiani, M.G. Social Perceptions and Forest Management Strategies in an Italian Alpine Community. Mt. Res. Dev. 2013, 33, 152-160. [CrossRef]

83. Paletto, A.; De Meo, I.; Cantiani, M.G.; Cocciardi, D. Balancing wood market demand and common property rights: A case study on a community in the Italian Alps. J. For. Res. 2014, 19, 417-426. [CrossRef]

84. Grilli, G.; Balest, J.; De Meo, I.; Garegnani, G.; Paletto, A. Experts' opinions on the effects of renewable energy development on ecosystem services in the Alpine region. J. Renew. Sustain. Energy 2016, 8, 013115. [CrossRef]

85. Paletto, A.; Geitner, C.; Grilli, G.; Hastik, R.; Pastorella, F.; Rodríguez García, L. Mapping the value of ecosystem services: A case study from the Austrian Alps. Ann. For. Res. 2015, 58, 157-175. [CrossRef]

86. Sacchelli, S.; Garegnani, G.; Geri, F.; Grilli, G.; Paletto, A.; Zambelli, P.; Ciolli, M.; Vettorato, D. Trade-off between photovoltaic systems installation and agricultural practices on arable lands: An environmental and socio-economic impact analysis for Italy. Land Use Policy 2016, 56, 90-99. [CrossRef]

87. European Union 2013. Mapping and Assessment of Ecosystems and their Services. An Analytical Framework for Ecosystem Assessments under Action 5 of the EU Biodiversity Strategy to 2020. Available online: http://ec.europa.eu/environment/nature/knowledge/ecosystem_assessment/pdf/ MAESWorkingPaper2013.pdf (accessed on 10 June 2016).

88. Burkhard, B.; Kroll, F.; Nedkov, S.; Müller, F. Mapping ecosystem service supply, demand and budget. Ecol. Indic. 2012, 21, 17-29. [CrossRef]

89. Grunewald, K., Bastian, O. (Eds.) Ökosystemdienstleistungen: Konzepte, Methoden und Fallbeispiele; Spektrum Akademischer Verlag: Heidelberg, Germany, 2012. (In German)

90. Häyhä, T.; Franzese, P.P. Ecosystem services assessment: A review under an ecological-economic and systems perspective. Ecol. Model. 2014, 289, 124-132. [CrossRef]

91. Goulder, L.H.; Kennedy, D. Interpreting and estimating the value of ecosystem services. In Natural Capital: Theory \& Practice of Mapping Ecosystem Services; Kareiva, P.M., Tallis, H., Ricketts, T.H., Daily, G.C., Polasky, S., Eds.; Oxford University Press: New York, NY, USA, 2011; pp. 15-25.

92. Goio, I.; Gios, G.; Pollini, C. The development of forest accounting in the province of Trento (Italy). J. For. Econ. 2008, 14, 177-196. [CrossRef]

93. Häyhä, T.; Franzese, P.P.; Paletto, A.; Fath, B.D. Assessing, valuing, and mapping ecosystem services in Alpine forests. Ecosyst. Serv. 2015, 14, 12-23. [CrossRef]

94. Notaro, S.; Paletto, A.; Raffaelli, R. The economic valuation of non-productive forest functions as an instrument towards integrated forest management. In The Multifunctional Role of Forest-Policies, Methods and Case Studies; Cesaro, L., Gatto, P., Pettenella, D., Eds.; EFI Proceedings No. 55; European Forest Institute: Joensuu, Finland, 2008.

95. Rodríguez García, L.; Curetti, G.; Garegnani, G.; Grilli, G.; Pastorella, F.; Paletto, A. La valoración de los servicios ecosistémicos en los ecosistemas forestales: Un caso de estudio en Los Alpes Italianos. Bosque 2016, 37, 41-52. (In Spanish) [CrossRef]

96. Martin, A.; Blowers, A.; Boersema, J. Paying for environmental services: Can we afford to lose a cultural basis for conservation? Environ. Sci. 2008, 5, 1-5. [CrossRef]

97. Fisher, B.; Turner, R.K.; Morling, P. Defining and classifying ecosystem services for decision making. Ecol. Econ. 2009, 68, 643-653. [CrossRef] 
98. Fu, B.J.; Su, C.H.; Wei, Y.P.; Willet, I.R.; Lü, Y.H.; Liu, G.H. Double counting in ecosystem services valuation: Causes and countermeasures. Ecol. Res. 2011, 26, 1-14. [CrossRef]

99. Spangenberg, J.; Settele, J. Precisely incorrect? Monetising the value of ecosystem services. Ecol. Complex. 2010, 7, 327-337. [CrossRef]

100. Riera, P.; Signorello, G.; Thiene, M.; Mahieu, P.A.; Navrud, S.; Kaval, P.; Rulleau, B.; Mavsar, R.; Madureira, L.; Meyerhoff, J.; et al. Non-market valuation of forest goods and services: Good practice guidelines. J. For. Econ. 2012, 18, 259-270. [CrossRef]

101. Spangenberg, J.; Settele, J. Value pluralism and economic valuation-Defendable if well done. Ecosyst. Serv. 2016, 18, 100-109. [CrossRef]

102. Egoh, B.; Reyers, B.; Rouget, M.; Richardson, D.M.; Le Maitre, D.C.; van Jaarsveld, A.S. Mapping ecosystem services for planning and management. Agr. Ecosyst. Environ. 2008, 127, 135-140. [CrossRef]

103. Kienast, F.; Bolliger, J.; Potschin, M.; Groot, R.S.; Verburg, P.H.; Heller, I.; Wascher, D.; Haines-Young, R. Assessing Landscape Functions with Broad-Scale Environmental Data: Insights Gained from a Prototype Development for Europe. Environ. Manag. 2009, 44, 1099-1120. [CrossRef] [PubMed]

104. Tasser, E., Schermer, M., Siegl, G., Tappeiner, U. (Eds.) Wir Landschaftmacher: Vom Sein und Werden der Kulturlandschaft in Nord-, Ost- und Südtirol; Athesia: Bozen, Italy, 2012. (In German)

105. Grilli, G.; Jonkisz, J.; Ciolli, M.; Lesinski, J. Mixed forests and ecosystem services: Investigating stakeholders' perceptions in a case study in the Polish Carpathians. For. Policy Econ. 2016, 66, 11-17. [CrossRef]

106. Lamarque, P.; Tappeiner, U.; Turner, C.; Steinbacher, M.; Bardgette, R.; Szukics, U.; Schermer, M.; Lavorel, S. Stakeholder perception of grassland ecosystem services in relation to knowledge on soil fertility and biodiversity. Reg. Environ. Chang. 2011, 11, 791-804. [CrossRef]

107. Palomo, I.; Martín-López, B.; Potschin, M.; Haines-Young, R.; Montes, C. National Parks, buffer zones and surrounding lands: Mapping ecosystem service flows. Ecosyst. Serv. 2013, 4, 104-116. [CrossRef]

108. Scolozzi, R.; Morri, E.; Santolini, R. Delphi-based change assessment in ecosystem service values to support strategic spatial planning in Italian landscapes. Ecol. Indic. 2012, 21, 134-144. [CrossRef]

109. Harrison, S.R.; Qureshi, M.E. Choice of stakeholder groups in multicriteria decision models. Nat. Resour. Forum 2000, 24, 1-19. [CrossRef]

110. Hislop, M. Involving People in Forestry: A Toolbox for Public Involvement in Forest and Woodland Planning; Forestry Commission: London, UK, 2004.

111. De Meo, I.; Cantiani, M.G.; Ferretti, F.; Paletto, A. Stakeholders' Perception as Support for Forest Landscape Planning. Int. J. Ecol. 2011. [CrossRef]

112. Sporcic, M.; Landekic, M.; Lovric, M.; Martinic, I. Planning and Decision Making Models in Forestry. Croat. J. For. Eng. 2011, 32, 443-456.

113. Tattoni, C.; Ciolli, M.; Ferretti, F. The fate of priority areas for conservation in protected areas: A fine-scale Markov chain approach. Environ. Manag. 2011, 47, 263-278. [CrossRef] [PubMed]

114. Wolfslehner, B.; Seidl, R. Harnessing Ecosystem Models and Multi-Criteria Decision Analysis for the Support of Forest Management. Environ. Manag. 2010, 46, 850-861. [CrossRef] [PubMed]

115. Ciolli, M.; Tattoni, C.; Ferretti, F. Understanding forest changes to support planning: A fine-scale Markov chain approach. Dev. Environ. Model. 2012, 25, 355-373.

116. Zambelli, P.; Lora, C.; Spinelli, R.; Tattoni, C.; Vitti, A.; Zatelli, P.; Ciolli, M. A GIS decision support system for regional forest management to assess biomass availability for renewable energy production. Environ. Model. Softw. 2012, 38, 203-213. [CrossRef]

117. Brown, G.; Reed, P. Values Compatibility Analysis: Using Public Participation Geographic Information Systems (PPGIS) for Decision Support in National Forest Management. Appl. Spat. Anal. Policy 2012, 5, 317-332. [CrossRef]

118. Herzig, A.; Ausseil, A.G.E.; Dymond, J.R. Spatial optimisation of ecosystem services. In Ecosystem Services in New Zealand: Conditions and Trends; Dymond, J.R., Ed.; Manaaki Whenua Press: Lincoln, New Zealand, 2013; pp. 511-523.

119. Verkerk, P.J.; Mavsar, R.; Giergiczny, M.; Lindner, M.; Edwards, D.; Schelhaas, M.J. Assessing impacts of intensified biomass production and biodiversity protection on ecosystem services provided by European forests. Ecosyst. Serv. 2014, 9, 155-165. [CrossRef] 
120. Cambero, C.; Sowlati, T. Assessment and optimization of forest biomass supply chains from economic, social and environmental perspectives-A review of literature. Renew. Sustain. Energy Rev. 2014, 36, 62-73. [CrossRef]

121. Malek, Ž.; Boerboom, L. Participatory Scenario Development to Address Potential Impacts of Land Use Change: An Example from the Italian Alps. Mt. Res. Dev. 2015, 35, 126-138. [CrossRef]

122. Reed, M.S.; Kenter, J.; Bonn, A.; Broad, K.; Burt, T.P.; Fazey, I.R.; Fraser, E.D.G.; Hubacek, K.; Nainggolan, D.; Quinn, C.H.; et al. Participatory scenario development for environmental management: A methodological framework illustrated with experience from the UK uplands. J. Environ. Manag. 2013, 128, 345-362. [CrossRef] [PubMed]

123. Walz, A.; Lardelli, C.; Behrendt, H.; Grêt-Regamey, A.; Lundstrom, C.; Kytzia, S.; Bebi, P. Participatory scenario analysis for integrated regional modelling. Landsc. Urban Plan. 2007, 81, 114-131. [CrossRef]

124. Garegnani, G.; Geri, F.; Zambelli, P.; Grilli, G.; Sacchelli, S.; Paletto, A.; Curetti, G.; Ciolli, M.; Vettorato, D. A New Open Source DSS for Assessment and Planning of Renewable Energy: r.green. Available online: http: //geomatica.como.polimi.it/workbooks/n12/FOSS4G-eu15_submission_94.pdf (accessed on 10 June 2016).

125. Steinigera, S.; Hay, G.J. Free and open source geographic information tools for landscape ecology. Ecol. Inform. 2009, 4, 183-195. [CrossRef]

126. Zambelli, P.; Gebbert, S.; Ciolli, M. Pygrass: An object oriented python application programming interface (API) for geographic resources analysis support system (GRASS) geographic information system (GIS). ISPRS Int. J. Geo Inf. 2013, 2, 201-219. [CrossRef]

127. Ciolli, M.; Garegnani, G.; Geri, F.; Zambelli, P.; Grilli, G.; Sacchelli, S.; Poljanec, A.; Miotello, F.; Paletto, A.; Balest, J.; et al. Applying r.green.biomassfor to Pilot Regions. In Proceedings of the International Conference Energy and Nature in the Alps: A Balancing Act-Recharge Green Final Conference, Sonthofen, Germany, 20-21 May 2015.

128. Paletto, A.; Cantiani, M.G.; De Meo, I. Public Participation in Forest Landscape Management Planning (FLMP) in Italy. J. Sustain. For. 2015, 34, 465-482. [CrossRef]

129. Polasky, S.; Nelson, E.; Pennington, D.; Johnson, K.A. The Impact of Land-Use Change on Ecosystem Services, Biodiversity and Returns to Landowners: A Case Study in the State of Minnesota. Environ. Resour. Econ. 2011, 48, 219-242. [CrossRef]

130. Polasky, S.; Nelson, E.; Camm, J.; Csuti, B.; Fackler, P.; Lonsdorf, E.; Montgomery, C.; White, D.; Arthur, J.; Garber-Yonts, B.; et al. Where to put things? Spatial land management to sustain biodiversity and economic returns. Biol. Conserv. 2008, 141, 1505-1524. [CrossRef]

131. Daily, G.C.; Polasky, S.; Goldstein, J.; Kareiva, P.M.; Mooney, H.A.; Pejchar, L.; Ricketts, T.H.; Salzman, J.; Shallenberger, R.M. Ecosystem services in decision making: Time to deliver. Front. Ecol. Environ. 2009, 7, 21-28. [CrossRef]

132. Grêt-Regamey, A.; Brunner, S.H.; Kienast, F. Mountain Ecosystem Services: Who Cares? Mt. Res. Dev. 2012, 32, 23-34. [CrossRef]

(C) 2016 by the authors; licensee MDPI, Basel, Switzerland. This article is an open access article distributed under the terms and conditions of the Creative Commons Attribution (CC-BY) license (http://creativecommons.org/licenses/by/4.0/). 